\title{
Interim Measures in International Commercial Arbitration: A Discourse in Continued Uncertainty
}

\author{
Noran Mohammed Al Mekhlafi \\ University of Dubai \\ Mail :nmmekhlafi@gmail.com
}

\begin{abstract}
The paper investigates the problem associated with the issue of interim measures in international arbitration, particularly, the power of arbitral tribunals to grant such measures and to enforce them. After an extensive and detailed analysis of various international arbitration rules, conventions and national systems the research finds that there is a great deal of uncertainty and confusion as to the issues underlying interim measures in international arbitration. In addition, national legislations on arbitration need to be clarified and adjusted to international best practices.
\end{abstract}

One of the main issues which the paper highlights is the limitation on national court's power to order interim measures. In several cases, it has been recorded that the availability of emergency arbitrator's provisions under institutional rules may significantly jeopardize the parties' existing right to seek court-ordered interim measures, which is not in line with what the arbitral institutions had intended upon providing these expediting provisions. Thus, the paper provides suggestions and recommendations towards more certainty in the treatment of interim measures in international arbitration.

Keywords : Arbitration, Interim Measures, Uncertainty 


\section{List of Abbreviations}

\begin{tabular}{|c|c|}
\hline US & United States of America \\
\hline UNCITRAL & United Nations Commission on International \\
& Trade Law \\
\hline ICC & International Chamber of Commerce \\
\hline AAA & American Arbitration Association \\
\hline LCIA & London Court of International Arbitration \\
\hline ICSID & International Centre for Settlement of Investment \\
& Disputes \\
\hline DIAC & Dubai International Arbitration Centre \\
\hline UK & United Kingdom \\
\hline
\end{tabular}




\section{INTRODUCTION:}

Arbitration is a private system for the resolution of disputes whereby parties agree to submit to neutral decision makers instead of national courts. An interim measure in arbitration is a preliminary relief that is granted before issuing a final award, for the purpose of ensuring that a relief on the disputed matter could still be available upon rendering a final award. Interim measures are always handled on an urgent basis before the arbitral tribunal is constituted or during the arbitration proceedings. Originally, in arbitration, interim relief was only available through national courts as opposed to arbitral tribunals. Some jurisdictions considered the agreement to arbitrate a waiver of the parties' right to seek national courts for interim measures. ${ }^{1}$ However, nowadays, it is generally understood that having an agreement to arbitrate does not prevent parties from seeking the court for granting interim measures.

Over the years, the independency of arbitration as an adjudication system has increased and distanced it from the involvement of national courts. Based on that, under most national jurisdictions, the arbitral tribunal has the power to issue interim measures once requested by one of the parties without the need to seek national courts for that purpose.

In situations of extreme urgency, it might be clear that a party to arbitration should seek the competent court for interim measures due to the urgency of the situation. However, such application to the competent court could lead to a series of issues and may not even be the right step to take in some cases. The question of whether to seek the competent court or the arbitral tribunal for interim measures in the first place depends the relevant national law and also the nature of the requested relief. Some laws make it clear that an application for an interim relief must be made first to the arbitral tribunal unless the parties agree otherwise, such as the Swiss law. ${ }^{2}$ Another arbitration law that is considered to be clear on the matter is English law, as it specifies the situations where parties to an arbitration agreement could seek the court for an application of interim measures or otherwise be compelled to seek the tribunal to issue such an order. ${ }^{3}$ Where the relevant law is not as clear as it should be regarding the matter, each case would be handled based on its unique circumstances and the urgency of the interim relief.

Similar to some national arbitration laws, the UNCITRAL Arbitration Rules states that parties may request the arbitral tribunal to grant interim measures in accordance with the specified conditions that must be satisfied. At the same time, it clearly states that requesting an interim relief from competent courts shall not be deemed incompatible with the arbitration agreement and does not waive the parties' right to arbitrate. ${ }^{4}$

\footnotetext{
${ }_{1}^{1}$ Margaret L. Moses, The Principles and Practice of International Commercial Arbitration (Cambridge University Press, Second Edition, 2012), P. 105.

${ }^{2}$ Nigel Blackaby and Constantine Partasides QC with Alan Redfern and Martin Hunter, Redfern And Hunter on International Arbitration (Oxford University Press, Sixth Edition, 2015), P. 425.

${ }^{3}$ Arbitration Act (1996), Section 44(3-5).

${ }^{4}$ UNCITRAL Arbitration Rules, Art. 26.
}

2523-6547 - Copyright: (C) 2017 The Authors. This is an open access article distributed under the terms of the Creative Commons Attribution License, which permits unrestricted use, distribution, and reproduction in any medium, provided the original author and source are credited 
The major issues under interim measures in arbitration arise from the power to order these measures and the power to enforce them. These issues are subject to a significant body of legal rules, national laws and international conventions, which do not necessarily provide certain answers. Therefore, it is vital to break down the existing issues in order to point out the inconsistencies and uncertainty that are found in practice. Thus, the problem sought to be addressed by this paper is how arbitration laws and rules can in general, be enhanced and harmonized to provide more certainty regarding interim measures.

In structuring the paper, the paper is divided into four broad sections. Section one provides a general overview and background of the problem. Section two, presents the issue of interim measures and discusses the powers of tribunals to grant such measures under the most relevant international conventions and institutional arbitration rules. Section three provides an analysis of national arbitration laws (randomly selected), through analyzing several court rulings concerning the issue of interim measures. The section also highlights specific issues of interim measures concerning the power to grant them and the power to enforce them. Section four concludes by responding to the problem explored and provides observations and recommendations towards more predictable legal regime governing interim measures in international arbitration.

\section{INTERIM MEASURES IN INTERNATIONAL ARBITRATION:}

As previously defined in the first section, interim measures ${ }^{5}$ are awards issued by a national court or an arbitral tribunal pending arbitral proceedings for the purpose of protecting or preserving the assets or claims of one of the parties. An interim measure is of a temporary nature pending the resolution of the dispute submitted to arbitration that aims to protect the rights of a party from being damaged or frustrated during the pendency of the arbitral process, which may take a considerable period of time; the risks involved could be substantial, especially in international disputes.

\subsection{Interim Measures under the Model Law}

The Model Law defines interim measures as follows:

“(2) An interim measure is any temporary measure, whether in the form of an award or in another form, by which, at any time prior to the issuance of the award by which the dispute is finally decided, the arbitral tribunal orders a party to:

\footnotetext{
${ }^{5}$ Also known as 'interim or conservatory measures' under the ICC Rules; 'provisional or conservatory measures' under the Swiss law; or preliminary measures; precautionary measures; preliminary injunctive measures; and urgent measures.
}

2523-6547 - Copyright: (C 2017 The Authors. This is an open access article distributed under the terms of the Creative Commons Attribution License, which permits unrestricted use, distribution, and reproduction in any medium, provided the original author and source are credited 
(a) Maintain or restore the status quo pending determination of the dispute;

(b) Take action that would prevent, or refrain from taking action that is likely to cause current or imminent harm or prejudice to the arbitral process itself;

(c) Provide a means of preserving assets out of which a subsequent award may be satisfied; or

(d) Preserve evidence that may be relevant and material to the resolution of the dispute."

As it can be seen, the Model Law took a huge step into harmonizing and unifying the understanding of interim measures in arbitration and its implications. Although such amendment made by the UNCITRAL Model Law may not be adopted as is, even by states that had adopted provisions of the Model Law, article 17 is indeed providing an approach that could have an influence on a large scale of national courts and arbitral tribunals. ${ }^{7}$

The Model Law also laid down the conditions under which an interim measure could be granted. Article 17 provides that a party applying for an interim measure before an arbitral tribunal must satisfy that, irreparable harm is likely to take place if the requested measure was not granted, and that the harm outweighs the harm that the other party may endure upon granting the requested interim measure. In addition, the party requesting an interim measure must prove to the arbitral tribunal that there exists a reasonable possibility of the requesting party succeeding in its claim. ${ }^{8}$

Besides clarifying the issue of interim measures, article 17 of the UNCITRAL Model Law -similar to many other arbitration rules and national laws- gives power to the arbitral tribunal to grant interim measures by default, unless the parties agreed otherwise in their arbitration agreement. ${ }^{9}$

\subsection{Exclusive or Concurrent}

Over the past few decades, there has been a gradual shift in international commercial arbitration towards establishing pro-arbitration legal regimes. Such objective entails supporting party-autonomy and the independency of arbitration from judicial intervention. The issue of interim measures reflects one essential aspect of that objective, which is the limitation of procedural intervention by national courts.

Not long ago in international arbitration, interim measures were considered to be subject to the exclusive jurisdiction of national courts under many national arbitration laws. Nowadays, most national and international arbitration laws and rules clearly recognize or even assume that national courts and arbitral tribunals do share concurrent jurisdiction to grant interim measures. ${ }^{10}$ However, the issue remains as to how and when each authority should intervene while maintaining the validity and effectiveness of the arbitral proceedings and the interim measure itself.

\footnotetext{
${ }^{6}$ UNCITRAL Model Law, Art. 17(2) (2006).

${ }^{7}$ Moses, (n 1), P. 106-107.

${ }^{8}$ UNCITRAL Model Law, Art. 17 A (1(a)(b)).

${ }^{9}$ Ibid, Art. 17(1).

${ }^{10}$ Moses, (n 1), P. 107.

2523-6547 - Copyright: (C) 2017 The Authors. This is an open access article distributed under the terms of the Creative Commons Attribution License, which permits unrestricted use, distribution, and reproduction in any medium, provided the original author and source are credited
} 
Undoubtedly, the principle of concurrent jurisdiction could serve the best interest of parties to arbitration in so many different ways, but only if it were carefully structured as to not create any further conflicts between both jurisdictions that would render the arbitral process ineffective. It can be safely assumed that the burden falls on national arbitration laws and how it could be enhanced and developed to reflect the best available international practice. Today, the international best practice regarding the issue at hand is assumed to be well established through international arbitration conventions, the Model Law and institutional rules.

\subsection{International Arbitration Conventions and Institutional Arbitration Rules}

The following table lays down all international legal provisions that are relevant to interim measures.

\begin{tabular}{|c|c|}
\hline ICSID & $\begin{array}{l}\text { Rule 39(1): "At any time after the institution of the } \\
\text { proceedings, a party may request that provisional } \\
\text { measures for the preservation of its rights be } \\
\text { recommended of which is requested, and the } \\
\text { circumstances that require such measures." }\end{array}$ \\
\hline Model Law & $\begin{array}{l}\text { Article 17(1): "Unless otherwise agreed by the } \\
\text { parties, the arbitral tribunal may, at the request of } \\
\text { a party, grant interim measures." } \\
\text { Article 9: "It is not incompatible with an } \\
\text { arbitration agreement for a party to request, } \\
\text { before or during arbitral proceedings, from a court } \\
\text { an interim measure of protection and for a court to } \\
\text { grant such measure." }\end{array}$ \\
\hline UNCITRAL Arbitration Rules & $\begin{array}{l}\text { Article 26(1): "The arbitral tribunal may, at the } \\
\text { request of a party, grant interim measures." }\end{array}$ \\
\hline ICC Rules & $\begin{array}{l}\text { Article 28(1): "Unless the parties have otherwise } \\
\text { agreed, as soon as the file has been transmitted to } \\
\text { it, the arbitral tribunal may, at the request of a } \\
\text { party, order any interim or conservatory measure } \\
\text { it deems appropriate..." }\end{array}$ \\
\hline AAA Rules & $\begin{array}{l}\text { Rule 37: “( a) the arbitrator may take whatever } \\
\text { interim measures he or she deems necessary, } \\
\text { including injunctive relief and measures for the }\end{array}$ \\
\hline
\end{tabular}

2523-6547 - Copyright: (C 2017 The Authors. This is an open access article distributed under the terms of the Creative Commons Attribution License, which permits unrestricted use, distribution, and reproduction in any medium, provided the original author and source are credited 


\begin{tabular}{|c|c|}
\hline & $\begin{array}{l}\text { protection or conservation of property and } \\
\text { disposition of perishable goods; (c) a request for } \\
\text { interim measures addressed by a party to a judicial } \\
\text { authority shall not be deemed incompatible with } \\
\text { the agreement to arbitrate or a waiver of the right } \\
\text { to arbitrate." }\end{array}$ \\
\hline LCIA Rules & $\begin{array}{l}\text { Article 25(1): "The arbitral tribunal shall have the } \\
\text { power upon the application of any party, after } \\
\text { giving all other parties a reasonable opportunity to } \\
\text { respond to such application and upon such terms } \\
\text { as the arbitral tribunal considers appropriate in } \\
\text { the circumstances. (i) to order any respondent } \\
\text { party to a claim or cross-claim to provide security } \\
\text { for all or part of the amount in dispute... (ii) to } \\
\text { order the preservation, storage, property, sale, or } \\
\text { other disposable of any documents, goods, } \\
\text { samples, property, site or thing under the control } \\
\text { of any party and relating to the subject matter of } \\
\text { the arbitration; and (iii) to order on a provisional } \\
\text { basis, subject to a final decision in an award, any } \\
\text { relief which the arbitral tribunal would have power } \\
\text { to grant in an award, including the payment of } \\
\text { money or the disposition of property as between } \\
\text { parties." }\end{array}$ \\
\hline DIAC $^{11}$ Rules & $\begin{array}{l}\text { Article 31(1): "Subject to any mandatory rules of } \\
\text { the applicable law, at the request of a party, the } \\
\text { tribunal may issue any provisional orders or take } \\
\text { other interim or conservatory measures it deems } \\
\text { necessary, including injunctions and measures for } \\
\text { the conservation of goods which form part of the } \\
\text { subject matter in dispute, such as an order for their } \\
\text { deposit with a third person or for the sale of } \\
\text { perishable goods..." }\end{array}$ \\
\hline
\end{tabular}

${ }^{11}$ Dubai International Arbitration Centre Arbitration Rules.

2523-6547 - Copyright: (C) 2017 The Authors. This is an open access article distributed under the terms of the Creative Commons Attribution License, which permits unrestricted use, distribution, and reproduction in any medium, provided the original author and source are credited 
As it may be obvious, most international legal provisions concerning interim measures in arbitration, if not all, do provide for the arbitral tribunal's right to grant interim measures at the request of one of the parties. These provisions are supposed to offer guidance and set a model for national legal systems to follow in order to conform to the international best practice.

\section{INTERIM MEASURES: ANALYSIS OF NATIONAL LEGAL SYSTEMS}

International arbitration functions in a way that is based on several legal sources at once, playing a substantial role in the outcome of the arbitral process. These different legal sources lead to different and inconsistent outcomes under each and every jurisdiction. As stated, these sources may include an international convention/treaty, the national legal system, and the institutional rules. However, first and foremost, the arbitral process must be carried out in accordance with the relevant national law; national courts are the body with the power to interpret, recognize and enforce. When it comes to breaking down the issue of interim measures, national legislation is the fundamental legal instrument that could cause and create confusion and uncertainty in international arbitration.

Furthermore, the major issue under interim measures is when the powers of the court and the powers of the arbitral tribunal crash together creating a conflict, thus, jeopardizing the arbitral process. When should the national court intervene and when should it refrain from doing so; it may be easy to lay down a typical perfect answer to such theoretical question, but it is indeed difficult to determine where and when that line should be drawn over the powers of the judicial authority.

\subsection{Powers to Grant Interim Measures under National Legislation and Court Rulings}

Generally speaking, most national arbitration laws have developed over the years and moved towards giving arbitral tribunals the power to order interim measures in accordance with the arbitration agreement of the parties. Anyhow, there are still some national laws that prohibit arbitral tribunals from granting interim measures and reserve such powers exclusively to the national court. Under few jurisdictions, such as China, Argentina and Italy; the power to order interim measures are exclusive to the judicial authority and arbitral tribunals are prohibited by law from ordering such. ${ }^{12}$ In an attempt to contemplate the rationale for such prohibition, it seems that there always has been an inherent reluctance by national courts to hand over some of its powers to arbitrators. There are indeed, many cases where the intervention of the national court is considered to be vital whenever circumstances arise preventing the arbitral tribunal from having the power to grant an interim measure. However,

\footnotetext{
12 Argentine Code of Civil and Commercial Procedure, Art. 753; Italian Code of Civil Procedure, Art. 818; Chinese Arbitration Law, Art. 68.

2523-6547 - Copyright: (C) 2017 The Authors. This is an open access article distributed under the terms of the Creative Commons Attribution License, which permits unrestricted use, distribution, and reproduction in any medium, provided the original author and source are credited
} 
in such case, a legal system that provide for concurrent jurisdiction between the national court and the arbitral tribunal can handle these situations as it provides the parties with the right to seek court-ordered interim measures instead.

As stated, there are several situations that could take place during the course of arbitration leading a party to favor court-ordered interim measures. In such situations, it might be that the arbitral tribunal's power is insufficient to grant a valid interim measures or that the party requesting the measure is favoring the national court to ensure the validity and effectiveness of the measure. ${ }^{13}$

One of the situations where the intervention of national courts is needed, is when the arbitral tribunal lacks the power to order interim measures, either because the measure involves a third party which the arbitral tribunal does not have jurisdiction over ${ }^{14}$, or due to the inability to act before the arbitral tribunal is constituted ${ }^{15}$.

\subsection{Effect of Emergency Arbitrator Provisions on The Court's Jurisdiction to Order Interim Measures}

In the case of Seele Middle East FZE v Drake \& Scull International SA CO, an application was made to the English High Court for an injunction in relation to a contract governed by English law, providing for arbitral proceedings under the ICC arbitration in London. ${ }^{16}$ The application was made on an urgent basis before commencement of the arbitral proceedings, under Section 44 of the Arbitration Act $^{17}$, which basically lays down the powers granted to English courts in support of arbitration seated in England and Wales. The court recognized the urgency of the application, satisfying Section 44(3), and further determined that at that point, the arbitral tribunal had no power to grant such measure, which is in accordance with Section 44(5). Thus, the court accepted jurisdiction and ordered the measure requested for the purpose of preserving evidence.

However, the court added an obiter $^{18}$ that stated:

"Although this is a matter where there is arbitration under the ICC Rules, it is not subject to the recent change in those rules in the form of the introduction of an emergency arbitrator to deal with applications. ${ }^{19}$ Therefore, there

${ }^{13}$ Redfern and Hunter, (n 2), P. 421.

${ }^{14}$ An arbitral tribunal's power is limited to the parties of the arbitration agreement and cannot go beyond the scope of its jurisdiction.

${ }^{15}$ Redfern and Hunter, (n 2), P. 422.

${ }^{16}$ Seele Middle East FZE v Drake \& Scull International SA CO [2013] EWHC 4350 (TCC).

\section{${ }^{17}$ See Section 44 English Arbitration Act 1996}

${ }^{18}$ Obiter Dictum is a Latin phrase meaning 'by the way', which is used legally to refer to an opinion or a remark stated within a decision by a judge that is unnecessary to the question of the case and not considered as part of the binding final judgment; merely an opinion said in passing.

${ }^{19}$ Referring to the 2012 amendment of the ICC Rules, which included provisions for an emergency arbitrator to order urgent measures, Art. 29(1): “A party that needs urgent interim or conservatory measures that cannot

2523-6547 - Copyright: (C 2017 The Authors. This is an open access article distributed under the terms of the Creative Commons Attribution License, which permits unrestricted use, distribution, and reproduction in any medium, provided the original author and source are credited 
is no power for the time being for an ICC arbitral tribunal to act effectively. Whether an emergency arbitrator would be able to act effectively is not a matter which I therefore need to consider." 20

The statement made by the judge, means that had the 2012 ICC Rules applied in that case, there might be a basis upon which an emergency arbitrator would have had the power to act effectively in response to the requested measure, thus, frustrating the powers of the court on that matter in accordance with Section 44(5) of the Arbitration Act. The implication of such notion is that a party exercising its right and seeking the national court for interim measures might find its application rejected due to the mere reason that an option to seek emergency measures under the ICC Rules exists. ${ }^{21}$

Such opinion triggers the question of whether the provisions of emergency arbitrator under institutional rules could limit the existing powers of the court to order interim measures. The language of the provisions of emergency measures merely provide for an expedited option to the parties that may be needed under many circumstances before the tribunal is constituted, however, such provisions are not of mandatory nature as to deny the court's jurisdiction once such option is merely available.

In another recent case, Gerald Metals SA v Timis, the court took a similar approach and held that where an expedited emergency arbitrator could be appointed under the LCIA Rules within the relevant timeframe, the court will have no jurisdiction to grant an urgent relief. ${ }^{22}$ This recent decision apparently supports the same argument that if an emergency arbitrator could be appointed and can exercise its powers to order the requested measure, the 'urgency' test provided for under Section 44(5) of the Arbitration Act will not be satisfied and thus, the court will have no power to order interim measures in that case.

The common factor here is the 'urgency' of the requested relief; it seems that as long as the 'urgency' has been dealt with under emergency provisions in the relevant institutional arbitration rules, and the power of the emergency arbitrator is attainable and available, the 'urgency' requirement under Section 44(5) will not be satisfied before English courts. Even though in the case of Gerald, the relevant institutional rules, LCIA, provides that the provision of the emergency arbitrator should not prejudice the parties' right to seek court-ordered measures and that such option should not be considered as an alternative or a substitute to such right ${ }^{23}$, it did not prevent the limitation of Section 44(5) from operating. ${ }^{24}$ In other words, English courts will only have the

await the constitution of an arbitral tribunal ("Emergency Measures") may make an application for such measures pursuant to the Emergency Arbitrator Rules in Appendix V."

${ }^{20}$ Seele v Drake (n 38).

${ }^{21}$ Susan Field, 'Narrowing the powers of the national courts to grant interim measures - A measure too far?', Kluwer Arbitration Blog, August 272015 <http://kluwerarbitrationblog.com/2015/08/27/narrowing-the-powersof-the-national-courts-to-grant-interim-measures-a-measure-too-far/> accessed 29 August 2017.

${ }^{22}$ Gerald Metals SA v Timis [2016] EWHC 2327 (Ch).

${ }^{23}$ LCIA Rules, Art. 9B (9.12): “Article 9B shall not prejudice any party’s right to apply to a state court or other legal authority for any interim or conservatory measures before the formation of the Arbitration Tribunal; and shall not be treated as an alternative to or substitute for the exercise of such right..."

${ }^{24}$ Chris Parker \& Aaron McDonald, 'ENGLISH HIGH COURT HAS NO JURISDICTION TO GRANT URGENT RELIEF UNDER ARBITRATION ACT WHERE URGENT RELIEF COULD BE GRANTED BY EXPEDITED TRIBUNAL OR EMERGENCY ARBITRATOR UNDER LCIA RULES' (2016) $<$ http://hsfnotes.com/arbitration/2016/10/07/english-high-court-has-no-power-to-grant-urgent-relief-under-

2523-6547 - Copyright: (C 2017 The Authors. This is an open access article distributed under the terms of the Creative Commons Attribution License, which permits unrestricted use, distribution, and reproduction in any medium, provided the original author and source are credited 
jurisdiction to grant interim measures in accordance with Section 44(3) of the Arbitration Act in cases where there is insufficient time to constitute an expedited tribunal or appoint an emergency arbitrator, and where a tribunal or an emergency arbitrator could not exercise their power to grant the requested measure. ${ }^{25}$

In summary, it seems that the availability of emergency arbitrator's provisions may jeopardize the parties' existing right to select the suitable forum upon requesting interim measures. As a result, in such cases, the court's ability to step in may be tied if the same approach was followed in subsequent cases, which was not at all what the institutional rules had intended by providing for provisions of emergency arbitrator. ${ }^{26}$ In order to escape such risk, parties to arbitration may need to consider the relevant national law, and then, maybe consider opting out of the emergency arbitrator's provision, as it is possible to do so under provisions of the institutional rules. ${ }^{27}$ However, opting out of the emergency arbitrator provisions can be disadvantageous on the other hand, as such is originally intended to support the arbitral process and ensure a speedy and effective procedure for ordering interim measures.

\subsection{National Courts' Jurisdiction to Order Interim Measures in International Commercial Arbitration}

In the case of Channel Group v Balfour Beatty Ltd, the House of Lords stayed the appellants' action seeking an injunctive relief to forbid the other party from ceasing work under their construction contract, which contained an arbitration agreement providing for Belgium as the seat of arbitration ${ }^{28}$. The appellant had concession from the UK and French governments to construct a project in England; the respondent was the commissioner of the project in England. ${ }^{29}$ The House of Lords held that English courts do not have the power to order an injunctive relief that is related to a foreign arbitration. ${ }^{30}$

The above decision indicates reluctance by English courts to order interim measures in respect to a foreign arbitration seated in a foreign state. It seems that English courts do not encourage insufficient forum shopping, which is a well-established argument in favor of preserving the integrity of the arbitral process. However, if such argument has indeed proven to be a valid one, would it be just if the jurisdiction to order interim measures was exclusive to the court of the seat of arbitration? Furthermore, even if such notion was remotely

arbitration-act-where-urgent-relief-could-be-granted-by-expedited-tribunal-or-emergency-arbitrator-under-lciarules/> accessed 15 August 2017.

${ }^{25}$ Ibid.

${ }^{26}$ Ibid.

${ }^{27}$ See, e.g., ICC Rules, Art. 29 (6(b, c)): "the emergency arbitrator provisions shall not apply if: (b) the parties have agreed to opt out of the emergency arbitrator provisions; or (c) the parties have agreed to another prearbitral procedure that provides for the granting of conservatory, interim or similar measures; LCIA Rules, Art. 9B (9.14): "Article 9b shall not apply if...(i) the parties had not agreed in writing to 'opt in' to Article 9B; or (ii) the parties have agreed in writing at any time to 'opt out' of Article 9B."

${ }^{28}$ Channel Tunnel Group Ltd. v Balfour Beatty Construction Ltd. [1993] AC 334.

${ }^{29} \mathrm{Ibid}$

${ }^{30}$ Ibid.

2523-6547 - Copyright: (C) 2017 The Authors. This is an open access article distributed under the terms of the Creative Commons Attribution License, which permits unrestricted use, distribution, and reproduction in any medium, provided the original author and source are credited 
accepted, is it reasonable to deny foreign-court ordered measures while in many cases, the domestic national court may not have the power to order measures in respect to assets located in another state? ${ }^{31}$ The fact remains that the answer to these questions cannot be conclusive, it depends on the national law of the state involved and the interpretation of the court itself; whether or not it would be willing to exercise its power, if existed.

\subsection{Effect of The New York Convention on The Availability of Interim Measures}

The New York Convention may not have a clear provision concerning interim or provisional measures, however, article II (3) has been interpreted in many instances to state the opposite. In McCreary \& Rubber $v$ $C E A T$, another case concerning an international arbitration, the claimant was seeking the US federal district court to assert its claims in terms of a breach of contract, and to further attach sums owed to the other party by a Pittsburgh bank; while the parties had an arbitration agreement that provided for arbitration seated in Belgium. ${ }^{32}$ The court held that the interim measure requested i.e. attachment of sums, is denied on the basis of article II (3) of the New York Convention. The court interpreted the article as to prohibit national courts from ordering interim measures i.e. attachment of sums, before the commencement of the arbitral proceedings. The approach taken in this particular case contradicts the interpretation of most US courts, academic commentaries and almost all other foreign courts. ${ }^{33}$

In another well-known case, Cooper $v$ Ateliers de la Motobecane ${ }^{34}$, the New York court of appeal took a similar approach in interpreting article II (3) of the New York Convention. The court held that the New York Convention precludes contracting states ${ }^{35}$ from granting an attachment i.e. interim measure, in respect to a pending arbitration; the court also considered the action itself, an attempt on part of the claimant to frustrate the arbitration. Furthermore, the court stated in its decision that the policy of the New York Convention will be preserved by limiting any pre-arbitral actions before national courts, and that judicial intervention shall be restricted until the arbitration in question ends with a final award. ${ }^{36}$ Such broad interpretation of the New York Convention was further adopted and followed by other judicial decisions in the US. ${ }^{37}$

Such decisions have been criticized that, among all other contracting states of the New York Convention, the US is the only state that had case law interpreting the convention in such way as to preclude pre-arbitration judicial intervention in respect to interim measures. ${ }^{38}$ However, many other lower courts in the US have refused

\footnotetext{
${ }^{31}$ Born, (n 12), P. 931.

${ }^{32}$ McCeary Tire \& Rubber Co. $v$ CEAT SpA, 501 F.2D (3 ${ }^{\text {rd }}$ Cir. 1974).

${ }^{33}$ Born, (n12), P. 905.

${ }^{34}$ Cooper v Ateliers De La Motobecane, S.A 442 N.E.2d 1239 (N.Y. 1982).

${ }^{35}$ States that had acceded to the New York Convention.

${ }^{36}$ Cooper v Ateliers, (n 57).

37 See, e.g., Drexel Burnham Lambert Inc. v Ruebsamen 139 A.D.2d 323 (N.Y. App. Div. 1988).

${ }^{38}$ Alan Scott Rau, 'Provisional Relief in Arbitration: How Things Stand in the United States', Journal of International Arbitration, (Kluwer Law International 2005, Volume 22 Issue 1), P. 27 $<$ http://www.kluwerarbitration.com/document/download/?ids=ipn25923\&searchTerm $=\% 22$ interim\%20measure s\%22> accessed 16 August 2017.
}

2523-6547 - Copyright: (C 2017 The Authors. This is an open access article distributed under the terms of the Creative Commons Attribution License, which permits unrestricted use, distribution, and reproduction in any medium, provided the original author and source are credited 
to follow Cooper and McCeary interpretation of article II (3) of the New York convention, and stressed that the article does not refer by any means, to the question of interim measures. ${ }^{39}$

These decisions clearly point out the inconsistencies in the arbitration case law in respect to interim measures. For instance, in the case of Channel Tunnel, the case was first heard by the commercial court, then moved to the court of appeal and finally reached the House of Lords; and each court provided different approaches in attempting to answer the question of jurisdiction to grant interim measures. ${ }^{40}$

The concept of concurrent jurisdiction in terms of ordering interim measures in arbitration supports the arbitral process in a way that allows the judicial authority and the arbitral tribunal to complement each other and facilitate the procedure upon which a final award could be rendered. Instead, international arbitration case law indicates the reluctance of judicial authorities to abide by that concept and its underlying purposes, which is still creating endless uncertainty within the field.

\subsection{Enforcement of Interim Measures Granted by Arbitral Tribunals}

As demonstrated above, the power of the arbitral tribunal to order interim measures is well established within international arbitration under most national laws and institutional rules. However, having the required jurisdiction to order interim measures does not necessarily indicate that such orders are considered enforceable by the relevant judicial authority. As arbitral tribunals do not have coercive powers to enforce their interim measures, the matter of enforcement is solely subject to the discretion of the competent national court. In that regard, many national arbitration laws are yet to clarify their standing through explicit legal provisions; instead, the issue of enforcing interim measures ordered by arbitral tribunals is usually dealt with under the general statutory provisions governing arbitral awards. ${ }^{41}$

In the case of international arbitration, the national court may enforce an interim measure based on provisions of the New York Convention. In a recent case, Four Seasons Hotels v Consorcio Barr ${ }^{42}$, the arbitral tribunal issued a "partial award' 43 that ordered the other party to arbitrate, and prohibited it from seeking a different forum for the resolution of the dispute in question. The court enforced the partial award i.e. the interim measure, under the provisions of the New York Convention. This means that this might be one way to ensure the enforceability of the interim measure in a contracting state to the New York Convention. In this case, the claimant had previously applied to the US federal district court to obtain the same measure, and the request was denied. Same request was later enforced as a partial award by the court under the New York Convention.

\footnotetext{
${ }^{39}$ Born, (n 12), P. 906.

${ }^{40}$ Redfern and Hunter, (n 2), P. 434.

${ }^{41}$ Born, (n 12), P. 897.

${ }^{42}$ Four Seasons Hotels and Resorts v Consorcio Barr S.A., 377 F.3D 1164 (11 ${ }^{\mathrm{TH}}$ Cir. 2004).

${ }^{43}$ Partial awards are awards issued by arbitral tribunals, relating only to part of the dispute; either concerning a substantive or a procedural claim; the term is sometimes used in referring to interim measures; See, Moses, (n 1), P. 191.
}

2523-6547 - Copyright: (C) 2017 The Authors. This is an open access article distributed under the terms of the Creative Commons Attribution License, which permits unrestricted use, distribution, and reproduction in any medium, provided the original author and source are credited 
It follows, that enforcement of interim measures ordered by arbitral tribunal under the New York Convention may only take place if the measure was considered by the court to be a final award ${ }^{44}$, or if the measure taken was termed 'partial award'. ${ }^{45}$

On the other hand, the Model Law has attempted to ratify the issue of enforcement of interim measures by the inclusion of article $17 \mathrm{H}$. The article states that:

“(1) An interim measure issued by an arbitral tribunal shall be recognized as binding and, unless otherwise provided by the arbitral tribunal, enforced upon application to the competent court, irrespective of the country in which it was issued, subject to the provisions of article 17 I..."46

By making the above article subject to article $17 \mathrm{I}^{47}$, the Model Law ensures that refusal of recognition and enforcement of interim measures is subject to a limited set of circumstances. Accordingly, interim measures issued in a foreign state can be enforced in states that had adopted the Model Law, particularly, article 17, without the need to seek enforcement under the New York Convention. The advantage is that the provision of the Model Law, does not require the measure -sought to be enforced- to be in the form of a final award or else; as long as the measure in question falls within the definition of interim measures as provided under the Model Law itself. ${ }^{48}$

\footnotetext{
${ }^{44}$ See, Yasuda Fire \& Marine Ins. Co. v Continental Cas., 37 F.3d 345 ( $7^{\text {th }}$ Cir. 1994).

${ }^{45}$ Moses, (n 1), P. 112.

${ }^{46}$ UNCITRAL Model Law, Art. 17 H (1).
}

${ }^{47}$ Art. 17 I provides that: "(1)Recognition or enforcement of an interim measure may be refused only: (a) At the request of the party against whom it is invoked if the court is satisfied that: (i) Such refusal is warranted on the grounds set forth in article 36(1)(a)(i), (ii), (iii) or (iv); or (ii) The arbitral tribunal's decision with respect to the provision of security in connection with the interim measure issued by the arbitral tribunal has not been complied with; or (iii) The interim measure has been terminated or suspended by the arbitral tribunal or, where so empowered, by the court of the State in which the arbitration takes place or under the law of which that interim measure was granted; or $(b)$ If the court finds that: (i) The interim measure is incompatible with the powers conferred upon the court unless the court decides to reformulate the interim measure to the extent necessary to adapt it to its own powers and procedures for the purposes of enforcing that interim measure and without modifying its substance; or (ii) Any of the grounds set forth in article 36(1)(b)(i) or (ii), apply to the recognition and enforcement of the interim measure. (2) Any determination made by the court on any ground in paragraph (1) of this article shall be effective only for the purposes of the application to recognize and enforce the interim measure. The court where recognition or enforcement is sought shall not, in making that determination, undertake a review of the substance of the interim measure."

${ }^{48}$ Moses, (n 1), P. 112.

2523-6547 - Copyright: (C) 2017 The Authors. This is an open access article distributed under the terms of the Creative Commons Attribution License, which permits unrestricted use, distribution, and reproduction in any medium, provided the original author and source are credited 
As to interim measures ordered by an emergency arbitrator, national legislation remains silent on the matter with no clarification as to whether measures ordered by an emergency arbitrator would be considered as if an arbitral tribunal has issued them. ${ }^{49}$ A promising step has been taken by Singapore in regard to such issue, as it has introduced an amendment clarifying that:

"Interim measures ordered by a tribunal fall within the definition of "award", and that an emergency arbitrator is to be regarded as falling within the definition of an "arbitral tribunal"., 50

Such amendment provides clarification and certainty to the field, which is a recommended clarification that needs to be followed by other national legislations systems. The clarification ensures that interim measures will be subject to the same enforcement standards as final arbitral awards, and that an emergency arbitrator is considered as an arbitral tribunal with all what that entails.

To sum up, the uncertainty existing under international commercial arbitration in terms of granting and enforcing interim measures remains. Even though notable efforts have been made by several national legislation systems to conform to the framework stipulated under international conventions, institutional rules and even the Model Law; the fact remains, that in the absence of a harmonized international arbitration system, uncertainty and ambiguity will further continue within the field.

\section{CONCLUSION:}

From the foregoing analysis, the major issues underlying interim measures can be classified into the following; issues involving the power/jurisdiction to grant interim measures, issues related to emergency arbitrator provisions and issues concerning the enforceability of interim measures by the judicial authorities.

In terms of the power to grant interim measures, it is conclusive that most legal jurisdictions today supports the concurrent jurisdiction between arbitral tribunals and national courts. ${ }^{51}$ Institutional rules also have provisions allowing for concurrent jurisdiction to grant interim measures. ${ }^{52}$ Hence, in accordance with the relevant applicable rules of arbitration, national legislation allows parties to seek court-ordered measures or tribunalordered measures unless the parties to arbitration have agreed otherwise under their arbitration agreement.

\footnotetext{
${ }^{49}$ Chester Brown, 'The Enforcement of Interim Measures Ordered by Tribunals and Emergency Arbitrators in International Arbitration', in Albert janvan den Berg 9ed), International Arbitration: The Coming of a New Age?, ICCA Congress Series, Volume 17 (Kluwer Law International, 2013), P. 289

$<$ http://www.kluwerarbitration.com/document/kli-ka-icca-cb1723?q=\%22enforcement \%20of\%20interim\%20measures\%22> accessed 25 August 2017.

${ }^{50}$ Ibid; International Arbitration Act (Section 143A), (1994), Revised Edition 2002.

${ }^{51}$ See, e.g., English Arbitration Act, Arts. 39(1), 44(1); Singapore Arbitration Act, Arts. 28(1),31(1); German Arbitration Act, Section 1033, 1041.

${ }^{52}$ See, e.g., AAA Arbitration Rules, Rule 37(a)(c); ICC Rules, Art. 28; LCIA Rules, Art. 25.
}

2523-6547 - Copyright: (C) 2017 The Authors. This is an open access article distributed under the terms of the Creative Commons Attribution License, which permits unrestricted use, distribution, and reproduction in any medium, provided the original author and source are credited 
In order to set up a more harmonized structure for the issue of interim measures, the Model Law introduced provisions that sorts out the issue in a way that could be adopted and followed by national legislative bodies. The provisions of the Model Law concerning interim measures, as laid down under article 17 in specific, is considered to have provided a proper guideline for judicial authorities and arbitral tribunals in dealing with interim measures with a much more consistent approach. ${ }^{53}$ A number of institutional rules have also taken a step toward harmonizing their provisions of interim measures and adopted the provisions of emergency arbitrators. However, national legislation does not seem to provide the same concerning the provisions of emergency arbitrator. Most jurisdictions did not conform to the newly developed concept of an emergency arbitrator, hence, the power of the emergency arbitrator may not equal the power of an arbitral tribunal in many jurisdictions, and accordingly any orders made by the emergency arbitrator may not be subject to easy enforcement in many states due to questions of its validity.

Furthermore, as discussed above in section three, the emergency arbitrator provisions, though advantageous in nature, can form another obstacle under the issue of interim measures, which is limiting the court's intervention, once needed. It is indeed recognized under almost all international arbitration rules and laws, that the judicial authority does hold certain powers over the arbitral process, and that such power cannot be undermined or prejudiced in any possible form. The fact that the provisions of the emergency arbitrator has limited the powers of the court to act in support of arbitration in several court rulings, indicates that the spirit of the expediting provisions was not properly understood and was indeed, falsely interpreted in many cases. ${ }^{54}$

Concerning the issue of the power to grant interim measure, there seems to exist a great confusion as to where the powers of each side begins and where does it end; and as to when should such powers be exercised, even when they do exist. The research showed that some courts may be reluctant to not use their existing powers and end up over-using them, while some courts in some cases decide not to intervene and exercise their existing powers, even when they are urgently needed.

As to the issue of enforcement, it is well known that the arbitral tribunal does not have coercive powers at its disposal and thus, cannot enforce its awards or orders. The judicial authority is the one with the power to recognize and enforce such orders or measures even when an arbitral tribunal has issued them. The problem here may exist whenever there is a lack of a consistent understanding and interpretation of what the relevant international conventions have intended upon drafting their provisions. Whether or not interim measures in international arbitration could be enforced by virtue of the New York Convention; is a valid question that may be worth addressing. Such can be possible if the court where the enforcement of the interim measure is sought, identifies the order in question as an arbitral tribunal that shall be enforced in accordance with the provisions of the New York Convention. In that regard, there seems to be a gap in how modern international arbitration functions in cases where cross-border enforcement of interim measures is needed.

\footnotetext{
${ }^{53}$ Moses, (n1), P. 107.

${ }^{54}$ See,e.g., Seele Middle East FZE v Drake \& Scull International SA CO; Gerald Metals SA v Timis.

2523-6547 - Copyright: (C 2017 The Authors. This is an open access article distributed under the terms of the Creative Commons Attribution License, which permits unrestricted use, distribution, and reproduction in any medium, provided the original author and source are credited
} 
In summary, the present status of the issue of interim measures in international arbitration, although developed intensively recently, still involves a great deal of confusion and a remaining uncertainty.

As it has been concluded above, the international arbitration norm provides for concurrent jurisdiction between the arbitral tribunal and the state courts to grant interim measures in support of arbitral proceedings. Although developments have taken place toward establishing a more independent adjudication system of arbitration, the fact remains that national courts have an essential role to play along with a responsibility to intervene in aid of arbitration whenever it is deemed necessary. In that regard, a Swiss arbitrator once said:

"The development of law and international arbitration has been marked by an obvious tendency to limit the possibilities of court intervention in the course of an arbitration. ...It may be that the tide is now turning: it is increasingly realized in international arbitration circles that the intervention of the courts is not necessarily disruptive of the arbitration. It may equally be definitely supportive... "55

Such notion may raise a question of whether national courts should retain more powers over the arbitral process if such is clearly needed to serve justice. However, finding the appropriate balance between the two concurrent jurisdictions and consolidating the principles of arbitration with the parties' right to reach a fair resolution, seems like the right answer. In that regard, many national legislations need to find a way to consolidate the two powers together as to not clash and end up harming the interests of the parties involved. It seems that the English Arbitration Act has found a way to strike an appropriate balance between the two powers and extensively dealt with a variety of situations where such clear structure is needed to avoid confusion.

As to the issue of enforcement, the need for a cross-border globalized enforcement system of interim measures is expected to have a major impact on the field. Although creating such a global system of enforcement seems like an impossible task considering all different legal backgrounds and different types of interim measures that are available under national legislations, it is a positive thing that the international arbitration system has survived this long without such a universal system. ${ }^{56}$ Without such system, national legislation need to conform to the international best practice as identified through the Model Law and institutional arbitration rules. The existing national arbitration systems are not defective in nature nor do they need a radical development to begin with; they only need to harmonize areas of the law under which most confusion and uncertainty arises.

\footnotetext{
55 Reymond, 'The Chanel Tunnel case and the law of international arbitration' (1993) 109 LQR 337, at 341, cited in Redfern and Hunter, (n 2), P. 439.

${ }^{56}$ V.V. (Johnny Veeder, 'The Need for Cross-border Enforcement of Interim Measures Ordered by a State Court In Support of the International Arbitral Process', in Albert Jan van den Berg (ed), New Horizons in International Commercial Arbitration and Beyond, ICCA Congress Series, Volum 12 (Kluwer Law International, 2005) P. $242-271$

$<$ http://www.kluwerarbitration.com/document/ipn27555?q=\%22enforcement $\% 20$ of $\% 20$ interim $\% 20$ measures $\%$ 22> accessed 25 August 2017.

2523-6547 - Copyright: (C 2017 The Authors. This is an open access article distributed under the terms of the Creative Commons Attribution License, which permits unrestricted use, distribution, and reproduction in any medium, provided the original author and source are credited
} 


\section{Primary Sources:}

\section{Bibliography}

\section{Statutes/Conventions/Rules}

Argentine Code of Civil and Commercial Procedure

English Arbitration Act

Chinese Arbitration Law

Convention on the Settlement of Investment Disputes

German Arbitration Act

Italian Code of Civil Procedure

New York Convention on the Recognition and Enforcement of Foreign Arbitral Awards

Singapore International Arbitration Act

The US Federal Arbitration Act

UNCITRAL Model Law

Commercial Arbitration Rules by the American Arbitration Association

DIAC Arbitration Rules

UNCITRAL Arbitration Rules

LCIA Arbitration Rules

International Chamber of Commerce (ICC) Arbitration Rules

2523-6547 - Copyright: (C) 2017 The Authors. This is an open access article distributed under the terms of the Creative Commons Attribution License, which permits unrestricted use, distribution, and reproduction in any medium, provided the original author and source are credited 
2523-6547 - Copyright: (C) 2017 The Authors. This is an open access article distributed under the terms of the Creative Commons Attribution License, which permits unrestricted use, distribution, and reproduction in any medium, provided the original author and source are credited 


\section{Cases \& Awards}

Channel Tunnel Group Ltd. v Balfour Beatty Construction Ltd., Commercial Court, 27 November 1991.

Channel Tunnel Group Ltd. v Balfour Beatty Construction Ltd., Court of Appeal, 22 January 2002.

Channel Tunnel Group Ltd. v Balfour Beatty Construction Ltd. [1993] AC 334.

Cooper v Ateliers De La Motobecane, S.A 442 N.E.2d 1239 (N.Y. 1982).

Drexel Burnham Lambert Inc. v Ruebsamen 139 A.D.2d 323 (N.Y. App. Div. 1988).

Four Seasons Hotels and Resorts v Consorcio Barr S.A., 377 F.3D 1164 (11 ${ }^{\mathrm{TH}}$ Cir. 2004).

Gerald Metals SA v Timis [2016] EWHC 2327 (Ch).

McCeary Tire \& Rubber Co. v CEAT SpA, 501 F.2D (3 ${ }^{\text {rd }}$ Cir. 1974).

Seele Middle East FZE v Drake \& Scull International SA CO [2013] EWHC 4350 (TCC).

Southern Seas Navigation Ltd v Petroleos Mexicanos of Mexico City, 606 F.Supp. 692 (S.D.N.Y. 1985).

Yasuda Fire \& Marine Ins. Co. v Continental Cas., 37 F.3d 345 ( $7^{\text {th }}$ Cir. 1994). 


\section{Secondary Sources:}

Blackaby and Partasides QC with Redfern and Hunter, Redfern And Hunter on International Arbitration (Oxford University Press, Sixth Edition, 2015).

Born, International Arbitration: Cases and Materials (Second Edition, Wolters Kluwer Law \& Business, 2015)

Born, International Commercial Arbitration (Second Edition, Wolters Kluwer Law \& Business, 2014)

Savage and Gaillard, Fouchard Gaillard Goldman on International Commercial Arbitration (Kluwer Law International, 1999).

Moses, The Principles and Practice of International Commercial Arbitration (Cambridge University Press, Second Edition, 2012).

Alan Scott Rau, 'Provisional Relief in Arbitration: How Things Stand in the United States', Journal of International Arbitration, (Kluwer Law International 2005, Volume 22 Issue 1), P. 27

<http://www.kluwerarbitration.com/document/download/?ids=ipn25923\&searchTerm=\%22interim\%20measures \%22> accessed 16 August 2017.

Chester Brown, 'The Enforcement of Interim Measures Ordered by Tribunals and Emergency Arbitrators in International Arbitration', in Albert janvan den Berg 9ed), International Arbitration: The Coming of a New Age?, ICCA Congress Series, Volume 17 (Kluwer Law International, 2013),

< http://www.kluwerarbitration.com/document/kli-ka-icca-cb17-

23?q=\%22enforcement $\% 20$ of $\% 20$ interim $\% 20$ measures $\% 22>$ accessed 25 August 2017.

Chris Parker \& Aaron McDonald, 'ENGLISH HIGH COURT HAS NO JURISDICTION TO GRANT URGENT RELIEF UNDER ARBITRATION ACT WHERE URGENT RELIEF COULD BE GRANTED BY EXPEDITED TRIBUNAL OR EMERGENCY ARBITRATOR UNDER LCIA RULES' (2016) < http://hsfnotes.com/arbitration/2016/10/07/english-high-court-has-no-power-to-grant-urgent-relief-underarbitration-act-where-urgent-relief-could-be-granted-by-expedited-tribunal-or-emergency-arbitrator-under-lcia-

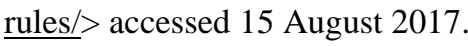

Lee Anna Tucker, 'Interim Measures under Revised UNCITRAL Arbitration Rules: Comparison to Model Law Reflects both Greater Flexibility and Remaining Uncertainty' International Commercial Arbitration Brief 1, no. 2 (2011).

Reymond, 'The Chanel Tunnel case and the law of international arbitration' (1993) 109 LQR 337, at 341.

Susan Field, 'Narrowing the powers of the national courts to grant interim measures - A measure too far?', Kluwer Arbitration Blog, August 272015 <http://kluwerarbitrationblog.com/2015/08/27/narrowing-the-powersof-the-national-courts-to-grant-interim-measures-a-measure-too-far/> accessed 29 August 2017.

2523-6547 - Copyright: (C) 2017 The Authors. This is an open access article distributed under the terms of the Creative Commons Attribution License, which permits unrestricted use, distribution, and reproduction in any medium, provided the original author and source are credited 
Treaty Between Sweden and The United States for The Advancement of Peace (1914): The American Journal of International Law, Vol. 10, No. 4, (American Society of International Law; Cambridge University Press) <https://www.jstor.org/stable/pdf/2212180.pdf?refreqid=excelsior\%3A0d635c267b1156924b6ca1d21ee29ea9> accessed 24 August 2017.

V.V. (Johnny Veeder, 'The Need for Cross-border Enforcement of Interim Measures Ordered by a State Court In Support of the International Arbitral Process', in Albert Jan van den Berg (ed), New Horizons in International Commercial Arbitration and Beyond, ICCA Congress Series, Volum 12 (Kluwer Law International, 2005) P. 242-271

<http://www.kluwerarbitration.com/document/ipn27555?q=\%22enforcement $\% 20$ of $\% 20$ interim $\% 20$ measures $\% 2$ 2> accessed 25 August 2017. 
2523-6547 - Copyright: (C) 2017 The Authors. This is an open access article distributed under the terms of the Creative Commons Attribution License, which permits unrestricted use, distribution, and reproduction in any medium, provided the original author and source are credited 